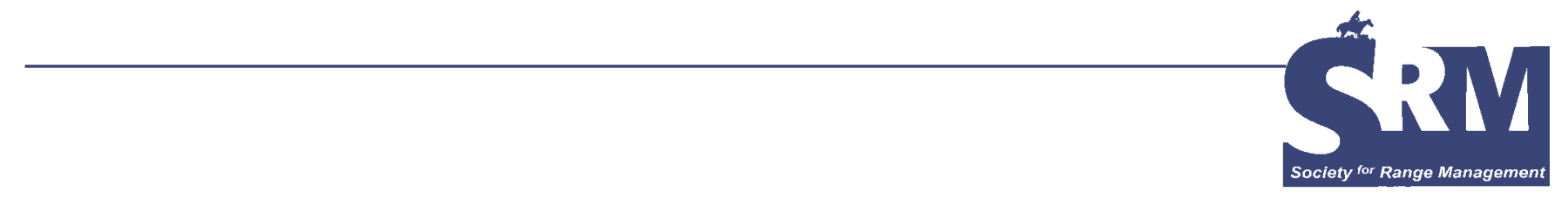

\title{
Cow Performance in Conventional Versus Early Weaning Herds in North Patagonia, Argentina
}

\section{By Nora Kugler, Hugo D. Giorgetti, Gustavo D. Rodríguez, Gustavo Cecchi, Oscar A. Montenegro, and Carlos A. Busso}

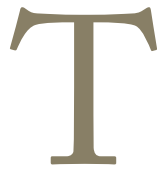

his paper demonstrates that early weaning should be included as an important management guideline in raising cattle in north Patagonia, Argentina. At most ranches, breeding takes place all year long. This makes it difficult to establish the weaning percentage (number of calves obtained per hundred bred cows). However, the calf-cow relationship, obtained from agrarian censuses and vaccination campaigns against aphthous, shows weaning values close to $60 \%$, with variations between $55 \%$ and $72 \%$, depending on zone and year.

Another consequence of continuous breeding and lack of enough paddocks is the premature pregnancy of young cows, which is harmful for their growth and subsequent pregnancies. Lack of adequate equipment, fences, watering points, etc. constrains proper use of renewable natural resources, with overgrazing in some cases and undergrazing in others. This is accompanied by a reduced livestock production. However, there exists low-cost technology adequate for these production systems, which allows one to improve cattle raising productive indices and rangeland vegetation productivity. ${ }^{1}$ An average weaning of $90 \%$ ( $84 \%$ to $100 \%$ ) and a weaning weight of 195 pounds (180 pounds to 200 pounds) was obtained in an eight-paddock rotational grazing system, which had a 3-mo (November, December, January) breeding season during late spring-early summer from 1988 to $1993 .^{2}$

Early weaning is defined as calf weaning at 2 mo, with the calf weighing between 154 and 177 pounds. Conventional weaning is defined as calf weaning at $6 \mathrm{mo}$. The advantages of an early weaning include 1) improvements in cow body state and pregnancy, especially in young cows of second parturition; 2) attenuation of emergency situations (i.e., scarcity of forage, reproductive problems because of a bad body condition, etc.); and 3) stocking rate increases. It is important to clarify the term "body," indicating either state or condition: animals are classified using a scale according to their fatness. In this work, a scale from 1 to 9 was used, where 1 corresponds to an extremely thin cow and 9 to a fat cow. ${ }^{3}$ Cow observations at the time of parturition, breeding, or tact (determining whether or not the cow was pregnant) allow proper management changes in time (i.e., a paddock change of the whole herd, a separation of cows in worst state from the herd, etc.). Cow body condition at parturition is related to the amount of days until breeding time and milk production. Cow state at breeding time influences the number of times that cow is ready for breeding until it becomes pregnant, and the time between parturitions.

During breeding, consumption must not be restricted because cows are suckling calves and they have to maintain a good body condition to become pregnant. The period of suckling has an adverse effect on reproduction. Lusby and Wettemann ${ }^{4}$ determined that weaning 2-yr-old cows of first parturition with very poor body condition ( 3 to $4^{3}$ ), increased pregnancy from $57 \%$ to $97 \%$ between 6 to $8 \mathrm{wk}$ after parturition. A pregnancy increase of $16 \%$ in 3-yr-old cows, and $28 \%$ in mature cows, was reported by Guyer ${ }^{5}$ when weaning was done $8 \mathrm{~d}$ before breeding. Early weaning in mature cows with a body condition of 5 , when compared with conventional weaning, ${ }^{1}$ shortened the period parturitionnew pregnancy from 81 to $46 \mathrm{~d}$, and increased pregnancy percentages from $83 \%$ to $100 \%{ }^{6}$ 
If early weaning is done all years in the herd, it is possible to increase stocking rates. But the question is, how much? In the northeast of Argentina, Provinces of Corrientes and Entre Ríos, cattle raising production has been increased after a 2 -mo weaning, increasing stocking rates up to $60 \%{ }^{7}$ This is because cows behave better when they do not have calves to maintain at the time range forage quality decays. In addition, greater herd control and organization allows managers to obtain better productive indices. ${ }^{7}$ Pordomingo ${ }^{8}$ increased cow number by $30 \%$ without constraining beef production after introducing an early weaning in the Province of La Pampa, Argentina. An increase of $20 \%$ in the amount of cows, and of $30 \%$ of cow-equivalent, were reported by Cocimano et al. ${ }^{9}$ when they compared the requirements of two herds using the National Research Counci ${ }^{10}$ tables, one with early weaning at $2 \mathrm{mo}$, and the other one with conventional weaning at $6 \mathrm{mo}^{1}{ }^{1}$

In the south of Buenos Aires Province, information was lacking on cows regarding the effects of early vs. conventional weaning. The objective of this work was to evaluate cow performance on two different herds where weaning was conducted either at 2 mo or 6 mo.

\section{Procedures}

This study was conducted at the Chacra Experimental de Patagones (40 $\left.39^{\prime} \mathrm{S}, 62^{\circ} 54^{\prime} \mathrm{W}\right)$, Provincia de Buenos Aires, Argentina, from October 1994 to May 1999 (Photo 1).

\section{Treatments}

There were two herds, which included both 58 cows and 3 Hereford bulls. Each herd (29 cows each) was assigned either to conventional or early weaning. In conventional weaning, weaning was done at 6 mo with an annual mean stocking rate of 19.3 acres per cow. Surface area assigned to this herd was 538 acres. Breeding was done in November, December, and January (midspring to early summer). In the early weaning herd, weaning was done at 2 mo with an

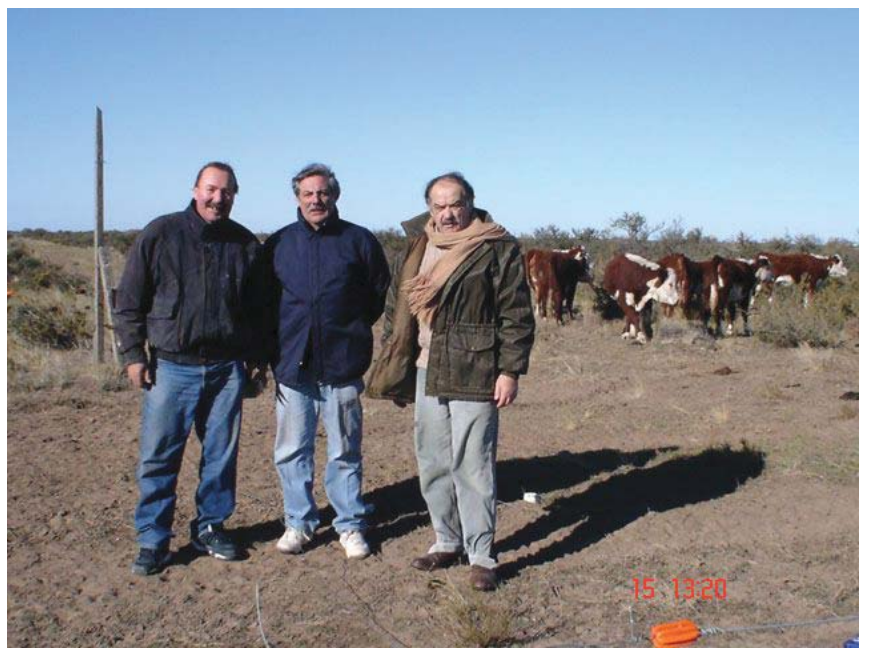

Photo 1. From left to right: C. A. Busso, H. D. Giorgetti, and O. A. Montenegro at facilities in the Chacra Experimental de Patagones. annual mean stocking rate of 13.8 acres per cow. Surface area assigned to this herd was 415 acres. Breeding was done in November, December, and January in 1994, and November and December in 1995 to 1998. Cows were weighed every $28 \mathrm{~d}$ from October until 2 mo before parturition. From 1995 onward, body condition was also determined at weighing time following the scale of Herd and Sprott. ${ }^{3}$ When weaning was done in the conventional weaning treatment, tact was done on all cows. All cows that were not pregnant, did not have teeth, or had eye problems were replaced.

\section{Forage Resources}

Vegetation was dominated by low shrubs that had nonexistent, reduced, or coriaceous leaves. This shrubland was partly open to cattle and had a winter herbaceous layer. Shrubs included Larrea divaricata, Geoffroea decorticans, Condalia microphylla, Prosopis alpataco, Cassia aphylla, Chuquiraga erinacea, Prosopidastrum globosum, and Lycium chilense. Herbaceous species were classified according to their palatability. Periodic clippings were conducted to estimate rangeland herbaceous species productivity, and the species were sorted out according to their palatability (Table 1).

Forage availability and cattle requirements at different times of its productive cycle were taken into account to determine the length of stay in each paddock. Forage availability was adjusted with the goal of reaching good rangeland condition. With this purpose in mind, the tendency and cover coefficient of Anderson ${ }^{11}$ was followed. It considers $100 \%$ of the palatable perennials, $50 \%$ of the intermediate perennials, and a variable percentage of annuals, depending on time of the year. This was the assigned forage from the total forage production. A utilization coefficient of $70 \%$ from the total available forage was used. The stay in any paddock was calculated as follows: Stay $($ days $)=$ surface $($ acres $) \times$ assigned forage availability (pounds of dry matter per acre)-stocking rate $^{-1}$ (acres per cow equivalent). Cow equivalent was defined by Giorgetti et al. ${ }^{1}$ Using the mentioned utilization coefficient, each herd grazed a different set of eight paddocks in rotation. Each paddock had an average surface area of 67 acres in the conventional weaning herd, and 52 acres in the early weaning herd. Stay and grazing frequency in this rotation system varied according to the forage grown each year (Table 2). The high instantaneous stocking rate that was used reduced the animal selectivity of forage to its minimum expression. This is because the stay in each paddock was not long enough as to allow grazing of regrowth.

\section{Forage Availability Estimate}

Every time cows entered any paddock, vegetation contained in 10 samples of 387.5 square inches each was clipped to 1.6 inches to estimate forage availability. It was then separated by species, oven-dried to $158^{\circ} \mathrm{F}$, and weighed. More than $50 \%$ of the total plant biomass was composed by palatable 
Table 1. Major herbaceous forage species in the "Monte" (steppe scrub dominated by microphyllous, xerophytic shrubs from 1 to $3 \mathrm{~m}$ height)

\begin{tabular}{l|l}
\hline Palatability & \multicolumn{1}{c}{ Genus and species } \\
\hline Palatable, perennial & Stipa tenuis, S. clarazii, S. papposa, Poa ligularis, Pappophorum subbulbosum \\
\hline Intermediate (less preferred), perennials & Piptochaetium napostaense, S. speciosa \\
\hline Palatable, annuals & Bromus spp., Medicago spp., Erodium cicutarium \\
\hline
\end{tabular}

Table 2. Rainfall and total (palatable + intermediate perennial grasses + annuals) forage production during the specified periods with the conventional and early weaning herds

\begin{tabular}{|l|c|c|c|c|c|}
\hline & $\begin{array}{c}\text { October 1994 } \\
\text { to March 1995 }\end{array}$ & $\begin{array}{c}\text { April 1995 to } \\
\text { March 1996 }\end{array}$ & $\begin{array}{c}\text { April 1996 to } \\
\text { March 1997 }\end{array}$ & $\begin{array}{c}\text { April 1997 to } \\
\text { March 1998 }\end{array}$ & $\begin{array}{c}\text { April 1998 to } \\
\text { March 1999 }\end{array}$ \\
\hline Rainfall (inches) & 5.54 & 10.16 & 22.35 & 21.92 & 9.96 \\
\hline $\begin{array}{l}\text { Conventional } \\
\text { weaning } \\
\text { (pounds:acre-1) }\end{array}$ & 322 & & & & \\
\hline $\begin{array}{l}\text { Early weaning } \\
\text { (pounds:acre-1) }\end{array}$ & 533 & 221 & 261 & 699 & 1,187 \\
\hline
\end{tabular}

perennial grasses such as Stipa tenuis, S. longiglumis, and Poa ligularis, and $27 \%$ corresponded to intermediate, less palatable perennial grasses (i.e., Piptochaetium napostaense, Stipa speciosa, and Aristida spp.). An average of the total forage dry matter produced $\cdot \mathrm{acre}^{-1} \cdot \mathrm{yr}^{-1}$ was obtained from the eight paddocks for each of the two herds (Table 2).

\section{Findings}

\section{Productive Indices}

Productive indices were similar in both herds (Table 3). The greatest difference in the pregnancy and weaning percentages, mainly for the conventional weaning herd, occurred during the cycle 1996-1997 (Table 3). This was very likely a result of several years of drought, which reduced forage production (Table 2) and stay paddock $^{-1}$ (data not shown). A greater number of parturitions was reached during the first month in the early weaning group than in the conventional herd (Table 4). A breeding time of $60 \mathrm{~d}$ had been used in the early weaning herd. A sequence of $4 \mathrm{yr}$ (1993, 13.2 inches; 1994, 12.1 inches; 1995, 10.9 inches; and 1996, 13.5 inches) with rainfall lower than the longterm annual rainfall (15.1 inches, 1988-1998) reduced rangeland total forage production during 1994-1996 by $66 \%$ on average with respect to a year with average rainfall
(701 pounds dry matter $\left.\cdot \mathrm{acre}^{-1}\right)$. This influenced the state of cows, producing a marked parturition displacement in the conventional herd. It did not happen with cows that were weaned early; because of this, cow requirements were reduced and this allowed parturition concentration within the first $45 \mathrm{~d}$ (Table 4 ). In ranches where breeding occurs all year long, a high percentage of calves is born in spring. However, there is always a group of calves born later on, which is variable in amount and has poor performance after weaning; in addition, these calves cause parturition displacement of their mothers. Instead, early weaning of this group would allow managers to concentrate breeding and parturitions.

\section{Cow Body Condition}

With the exception of 8.0, 6.8, and 0.2 values, average body condition in both herds varied between 4.0 and 5.4 during October 1995 and April 1999 (Table 5). During tact in March, both herds showed a similar body condition (Table 5). However, approximately half a point more in body condition in the early than in the conventional weaning herd at breeding allowed a pregnancy increase of 5\% (86\% and $91 \%$ pregnancy in the conventional and early weaning herds, respectively, during 1995-1999; Table 3).

\begin{tabular}{|c|c|c|c|c|c|c|c|c|c|c|}
\hline & \multicolumn{5}{|c|}{ Conventional Weaning } & \multicolumn{5}{|c|}{ Early Weaning } \\
\hline & $\begin{array}{c}1994- \\
1995\end{array}$ & $\begin{array}{c}1995- \\
1996\end{array}$ & $\begin{array}{c}1996- \\
1997\end{array}$ & $\begin{array}{c}1997- \\
1998\end{array}$ & $\begin{array}{c}1998- \\
1999\end{array}$ & $\begin{array}{c}1994- \\
1995\end{array}$ & $\begin{array}{c}1995- \\
1996\end{array}$ & $\begin{array}{c}1996- \\
1997\end{array}$ & $\begin{array}{c}1997- \\
1998\end{array}$ & $\begin{array}{r}1998- \\
1999\end{array}$ \\
\hline Pregnancy (\%) & 89 & 89 & 70 & 92 & 89 & 93 & 89 & 87 & 93 & 90 \\
\hline Weaning (\%) & 84 & 84 & 70 & 86 & 86 & 89 & 85 & 80 & 87 & 85 \\
\hline
\end{tabular}




\begin{tabular}{|c|c|c|c|c|c|}
\hline & 1994 & 1995 & 1996 & 1997 & 1998 \\
\hline Rainfall (inches) & 12.1 & 10.9 & 13.5 & 27.5 & 11.6 \\
\hline \multicolumn{6}{|c|}{ Conventional herd } \\
\hline August & 50 & 42 & 28 & 42 & 53 \\
\hline September & 46 & 46 & 48 & 21 & 40 \\
\hline October & 4 & 13 & 23 & 37 & 8 \\
\hline \multicolumn{6}{|c|}{ Early weaning herd } \\
\hline August & 45 & 50 & 72 & 58 & 65 \\
\hline September & 32 & 46 & 26 & 38 & 35 \\
\hline October & 23 & 4 & 2 & 4 & 0 \\
\hline
\end{tabular}

\begin{tabular}{|c|c|c|c|c|c|c|c|c|}
\hline & \multicolumn{4}{|c|}{ Conventional weaning } & \multicolumn{4}{|c|}{ Early weaning } \\
\hline & $\begin{array}{c}1995- \\
1996\end{array}$ & $\begin{array}{c}1996- \\
1997\end{array}$ & $\begin{array}{c}1997- \\
1998\end{array}$ & $\begin{array}{c}1998- \\
1999\end{array}$ & $\begin{array}{c}1995- \\
1996\end{array}$ & $\begin{array}{c}1996- \\
1997\end{array}$ & $\begin{array}{c}1997- \\
1998\end{array}$ & $\begin{array}{c}1998- \\
1999\end{array}$ \\
\hline October & 4.9 & 4.9 & 5.4 & 4.1 & 4.9 & 4.2 & 5.0 & 4.2 \\
\hline November & 4.8 & 4.3 & 5.3 & 4.5 & 5.1 & 4.3 & 6.8 & 4.5 \\
\hline December & 4.0 & 4.4 & 5.1 & 4.4 & 4.6 & 4.1 & 4.8 & 4.8 \\
\hline January & 4.0 & 4.2 & 5.2 & 4.3 & 4.3 & 4.3 & 4.9 & 4.9 \\
\hline February & 4.1 & 4.3 & 4.9 & 4.0 & 4.2 & 4.4 & 4.4 & 0.2 \\
\hline March & 4.3 & 4.3 & 4.7 & 4.1 & 4.2 & 4.3 & 4.6 & 4.5 \\
\hline April & 4.4 & 8.0 & 4.9 & 4.2 & 4.2 & 4.9 & 4.8 & 4.5 \\
\hline
\end{tabular}

\begin{tabular}{|c|c|c|c|c|c|c|c|}
\hline Herd & $\begin{array}{l}\text { October- } \\
\text { November }\end{array}$ & $\begin{array}{l}\text { November- } \\
\text { December }\end{array}$ & $\begin{array}{l}\text { December- } \\
\text { January }\end{array}$ & $\begin{array}{l}\text { January- } \\
\text { February }\end{array}$ & $\begin{array}{c}\text { February- } \\
\text { March }\end{array}$ & $\begin{array}{c}\text { March- } \\
\text { April }\end{array}$ & $\begin{array}{l}\text { April- } \\
\text { May }\end{array}$ \\
\hline $\begin{array}{l}\text { Conventional } \\
\text { weaning }\end{array}$ & 22.1 & -6.6 & -26.5 & -17.7 & -1.1 & 7.7 & 1.1 \\
\hline Early weaning & 19.9 & 1.1 & 4.4 & -16.5 & 13.2 & 9.9 & 22.1 \\
\hline
\end{tabular}

\section{Changes in Cow Live Weight}

Cows did not present great variations in their body condition. However, changes in live weight were measured, with large differences between both herds at some times during the year (data not shown). It is believed that live weight losses during breeding affected pregnancy levels and their distribution. Selk et al. ${ }^{12}$ reported that changes in cow live weight during gestation can affect reproductive performance independently of its body condition.

The difference in live weight between the two herds varied with time of the year (Table 6). In the conventional weaning herd, there was a loss in live weight during a 4-mo period (November and December-February and March; Table 6). At the same time, however, cows in the early 
weaning herd only lost weight during midsummer (Table 6).

\section{Conclusions}

The possibility of repeating the study during several consecutive years allowed us to arrive at important conclusions:

1) It was possible to increase cow numbers by $40 \%$ when using early weaning;

2) Increases in stocking rate did not a) produce negative results over the productive indices and allowed them to be maintained in years of scarce rainfall, b) constrain the herd body condition, or c) produce rangeland overuse;

3) Cow live weight loss was generally produced between November and January (late spring-early summer) in the conventional herd, whereas it was limited to midsummer in the early-weaning herd;

4) Early weaning allowed managers to concentrate pregnancy during the first breeding month;

5) Breeding should begin in October (early spring) because a) it reduces cows' weight loss during breeding and b) weaning can be anticipated. Precisely, early weaning was an important tool for constraining breeding to a specific period during the year;

6) Early weaning allows breeding of 15-mo-old cows. Otherwise, breeding is often conducted at 24 to 27 mo.

7) With the proposed rangeland management, most palatable perennial species were grazed with the same intensity as the less palatable, intermediate perennial species. In this way, the vegetation that could be more affected by grazing was preserved.

\section{References}

1. Giorgetti, H. D., C. A. Busso, O. A. Montenegro, G. D. Rodríguez, And N. M. Kugler. 2006. Cattle raising in central, semiarid rangelands of Argentina. Rangelands 28(1): 32-36.

2. Giorgetti, H., O. A. Montenegro, and G. D. Rodríguez. 1995. Unidad Experimental de cría bovina en campo de monte en el sur de la Provincia de Buenos Aires. Revista Argentina de Producción Animal 15:738-1194.

3. Herd, D. B., and L. R. Sprott. 1986. Body condition, nutrition and reproduction of beef cows. Texas Agricultural Extension Service, Bulletin B-1526.
4. Lusby, K. S., R. P. Wettemann, and E. J. Turman. 1981. Effects of early weaning calves from first calf heifers on calf and heifer performance. Journal of Animal Science 53:11931197.

5. Guyer, P. 1983. Management of early weaned calves. NebGuide. Lincoln, NE, USA: University of Nebraska. 6 p.

6. Lusby, K. S., and A. A. Parra. 1981. Effects of early weaning on calf performance and on reproduction in mature cows. Stillwater, OK, USA: Oklahoma State University, Oklahoma Agricultural Experiment Station Research Report MP 108. p. 64-68.

7. Monje, A., C. Hofer, and I. Galli. 1993. Destete precoz. Efecto sobre los vientres, manejo de terneros e impacto de la técnica sobre los sistemas de producción. Concepción del Uruguay, Entre Ríos, Argentina: Material de Divulgación Estación Experimental Agropecuaria INTA Concepción del Uruguay. p. 22-23.

8. Pordomingo, A. 1996. Destete precoz en la región semiárida. Santa Rosa, La Pampa, Argentina: Material de Divulgación Estación Experimental Agropecuaria Anguil. 71 p.

9. Cocimano, M., A. Lange, and E. Menvielle. 1975. Estudio sobre equivalencias ganaderas. Revista Argentina de Producción Animal 4:161-190.

10. National Research Council. 1996. Nutrient requirements of beef cattle. 7th ed. Washington, DC, USA: National Academy Press. 242 p.

11. Anderson, D. L. 1980. II. Curso de Pastizales, Villa Mercedes, San Luis. 1 al 5 de December. 18 p.

12. Selk, G. E., R. P. Wetteman, K. S. Lusby, J. W. Oltjen, S. S. Mobley, R. J. Rasby, and J. C. Garmendia. 1988. Relationships among weight change, body condition and reproductive performance of range beef cows. Journal of Animal Science 66:3153.

Authors are Rangeland Scientists, Estación Experimental Agropecuaria Valle Inferior-Convenio Provincia de Río NegroINTA, Ruta Nacional Nro. 3, km 971, Argentina (Kugler and Cecchi); Rangeland Scientists, Chacra Experimental de Patagones, Ministerio de Asuntos Agrarios, cc 118, 8504 Carmen de Patagones, Olivera 67, Argentina (Giorgetti, Rodríguez, and Montenegro); and Professor, Departamento de AgronomíaCentro de Recursos Naturales Renovables de la Zona Semiárida, Universidad Nacional del Sur, and Research Scientist of the Consejo Nacional de Investigaciones Científicas y Técnicas de la República Argentina, Altos del Palibue, 8000 Bahia Blanca, San Andrés 800,Argentina, cebusso@criba.edu.ar (Busso). 